\title{
Tissue CA-19.9 content in colorectal adenomas and its value in the assesment of dysplasia
}

\author{
I. Salces, I. Vegh², S. Rodríguez-Muñoz, F. Colina' ${ }^{1}$ A. Pérez ${ }^{1}$, S. Soto, F. Sánchez, J. de la Cruz ${ }^{3}$ \\ and J. A. Solís-Herruzo \\ Departments of Digestive Diseases, ${ }^{1}$ Pathology, ${ }^{2}$ Unit of Research: Research Center and ${ }^{3}$ Clinical Epidemiology Unit. \\ Hospital 12 de Octubre. Universidad Complutense. Madrid, Spain
}

\begin{abstract}
Background: occasionally, the risk of malignant transformation may be difficult to establish in adenomatous polyps due to the fact that they contain areas with variable grades of dysplasia. A measurement of tissue tumor markers may be useful to recognize these adenomas.

Objectives: the aims of this study were: to establish firstly the relationship between carbohydrate antigen 19.9 (CA-19.9) content in the colorectal mucosa and the characteristics of polyps, and secondly, the diagnostic value of the former's measurement.

Patients and methods: tissue CA-19.9 concentration was measured in 155 colorectal samples obtained from 145 patients (21 normal mucosa; 113 adenomatous polyps; 21 adenocarcinoma). Cytosol CA-19.9 content was determined by enzyme-linked immunoadsorbant assay, and the measurement of this protein was achieved by quantitative assay. Tissue samples were also processed for histological examination.

Results: we demonstrated that CA-19.9 levels in adenomatous polyps and adenocarcinomas were significantly higher than in the normal mucosa. These levels varied significantly according to polyp size, histological type, and grade of dysplasia. CA-19.9 contents were higher in polyps with a high risk of malignant transformation than in those with a low risk of severe dysplasia. The cut-off value $214 \mathrm{U} / \mathrm{mg}$ of protein properly differentiated both types of risk. The area under the receiver operating characteristic (ROC) curves showed that cytosol CA-19.9 levels allow classifying polyps according to their histological features.

Conclusions: we concluded that the measurement of CA19.9 content in adenomatous polyps may be useful to classify these tumors and confirm the feasibility to separate adenomas into two groups: low and high risk of malignant change.
\end{abstract}

Key words: Colorectal adenoma. Colonic polyps. Tissue tumor markers. CA-19.9. Dysplasia grade.

Recibido: $14-10-03$

Aceptado: $14-10-03$.

Correspondencia: Inmaculada Salces Franco. Servicio de Aparato Digestivo. Hospital Universitario 12 de Octubre. Avda. de Andalucía, km. 5,400. 28041 Madrid. Telf.: 913908409. Fax: 913908280.e-mail: luisframos@wanadoo.es
Salces I, Vegh I, Rodríguez-Muñoz S, Colina F, Pérez A, Soto $S$, Sánchez F, de la Cruz J, Solís-Herruzo JA. Tissue CA-19.9 content in colorectal adenomas and its value in the assesment of dysplasia. Rev Esp Enferm Dig 2004; 96: 246-254.

\section{INTRODUCTION}

It is well known that colorectal adenomas are tumors with a potential for developing carcinoma over a period of 5 to 15 years, and that this potential is related to the size of polyps, proportion of villous component, and grade of dysplasia (1-6). In some instances, the histological classification of polyps is difficult as these adenomas may contain areas with variable grades of dysplasia (7-10). The feasibility to discriminate groups of adenomas with different risks of malignant transformation could be important when choosing which polyps should be preferently polypectomized, or whether to increase the endoscopic surveillance or to consider an additional treatment (11).

The cytosolic carbohydrate antigen (CA-19.9) is a protein related to the monosyalilated Lewis antigen, which is expressed on the cell membrane and in the cytosol of human colorectal carcinoma as well as in the normal mucosa (12-18). Serum CA-19.9 levels are frequently used as a tumor marker, particularly for colon and pancreas cancer. A number of studies have shown the usefulness of this marker for assessing cancer progression, evaluating radical surgery or detecting recurrence (19-21). However, this tumor marker is often not detectable in the serum of patients with precancerous lesions, early cancer, and occasionally even advanced cancer. The low sensitivity of this tumor marker has been ascribed to a loss of tumor cells' capability to synthesize or release this antigen $(20,21)$. Moreover, its specificity is also low, since high levels of serum CA-19.9 have been detected in the serum 
of patients with other malignant and non-malignant conditions such as cancer of the liver, gallbladder, pancreas, stomach or breast, as well as pancreatitis, liver diseases or autoimmune diseases. It is to be expected that the measurement of this tumor protein in the tissue may be more sensitive and specific for recognizing a high risk of malignant transformation in colorectal adenomas. The aim of this study was to assess the value of the measurement of tissue CA-19.9 antigen in the classification of polyps according to the risk of malignancy.

\section{PATIENTS AND METHODS}

\section{Patients}

This study included 145 patients (97 men and 48 women) who underwent a full colonoscopy. An informed consent was obtained before their inclusion in the study. One hundred and fifty-five colorectal samples were collected endoscopically. In 21 cases the mucosa was normal, and in another 21 samples contained adenocarcioma. In the remaining 113 biopsies the histopathologic study showed adenomatous polyps that were removed from 103 patients. All samples were divided into two pieces; one of them was kept in $10 \%$ formol for histological examination, and the remaining piece was frozen in liquid nitrogen and stored at $-80{ }^{\circ} \mathrm{C}$ until CA-19.9 cytosol determination (4,22-24).

\section{Determination of CA-19.9 in colonic tissue}

Tissue CA-19.9 in the colon mucosa was measured using a microparticle enzimoimmunoassay (MEIA). Results obtained by this technique closely correlated with those recorded using a commercial radioimmunoassay (CA-19.9 RIA-gnost CIS Diagnostic, Madrid. Spain). Samples were thawed and homogenized at $4{ }^{\circ} \mathrm{C}$ with extraction buffer. Homogenates were centrifuged at $106,000 \mathrm{~g}$ for 30 minutes, and supernatants were collected for CA-19.9 assay and protein determination. This antigen was measured by a commercial assay (Abbott Cientifica, Madrid, Spain) based on the reaction between the monoclonal antibody 1116-NS-19.9 (12) and the carbohydrate antigen CA-19.9 determinant expressed on the cell surface. Cytosol CA-19.9 levels were expressed as units per milligram of protein $(\mathrm{U} / \mathrm{mg})$. Total tissue protein concentrations were determined according to Lowry et al. (25) (Bio-Rad Laboratories, Madrid, Spain).

\section{Histopathologic analysis}

Tissue samples were routinely processed and sections were stained with hematoxylin and eosin, periodateSchiff's reagent (PAS) with and without diastase digestion. Samples were analyzed by two independent pathologists who were unaware of the results of the CA-19.9 determination in tissue. Adenomas were classified according to their histological type (tubular, villous or tubulovillous) and dysplasia grade (mild, moderate, severe or carcinoma in situ).

The diagnosis of mild dysplasia was established when the glands showed elongation or branching, cell nuclei maintained their basal polarity in the cell, were slightly enlarged, oval, uniform in size, and with inconspicuous nucleoli.

Moderate dysplasia was considered when nuclei lost their basal polarity, became pseudostratified, and contained prominent nucleoli. In these cases glands were more crowded and branched, and contained no goblet cells.

Severe dysplasia was diagnosed when there was an important reduction of interglandular stroma with extreme glandular crowding and irregularity. Moreover, cell nuclei were pleomorphic, stratified with more prominent and numerous nucleoli, and increased nuclear-cytoplasmic ratio. Nuclear membranes were usually irregular and the chromatin pattern was hiperchromatic, vesicular or clumped.

Carcinoma in situ (CIS) was defined as a severe architectural distortion of glands with further cell proliferation within the crypt, loss of polarity, piled-up cells, and growth of glands within glands, resulting in a cribriform appearance or "back to back" pattern. Despite these changes, the basal membrane that surrounded these glands remained intact (26-28).

\section{Statistical analysis}

All data are expressed as mean \pm standard deviation. Due to the asymmetry and dispersion of CA-19.9 levels in tissue, a logarithmic transformation of these values was performed. An analysis of variance (ANOVA) was applied to establish the significance of differences when all groups of lesions were compared. $\mathrm{P}<0.05$ was considered statistically significant. The statistical performance of absolute antigen values and their logarithmic transformations were similar in every analysis. We also calculated sensitivity (S) and specificity (SP) rates, positive predictive value (PPV), negative predictive value (NPV), diagnostic efficiency (DE), and positive likelihood ratio (PLH) for the different tissue CA19.9 values $(29,30)$. Receiver operating characteristic (ROC) curves was performed to determine the diagnostic efficiency for the different variables and risk groups (31-34). All data were analysed using the statistical program SAS (SAS Inc, Cary, North Carolina 27513, USA).

\section{RESULTS}

\section{Tissue CA19.9 levels and diagnostic performance parameters}

Tissue CA19.9 values were $12.3 \pm 17.3 \mathrm{U} / \mathrm{mg}$ in the normal mucosa. These levels were significantly lower $(p<0.001)$ than those found in adenomatous polyps 


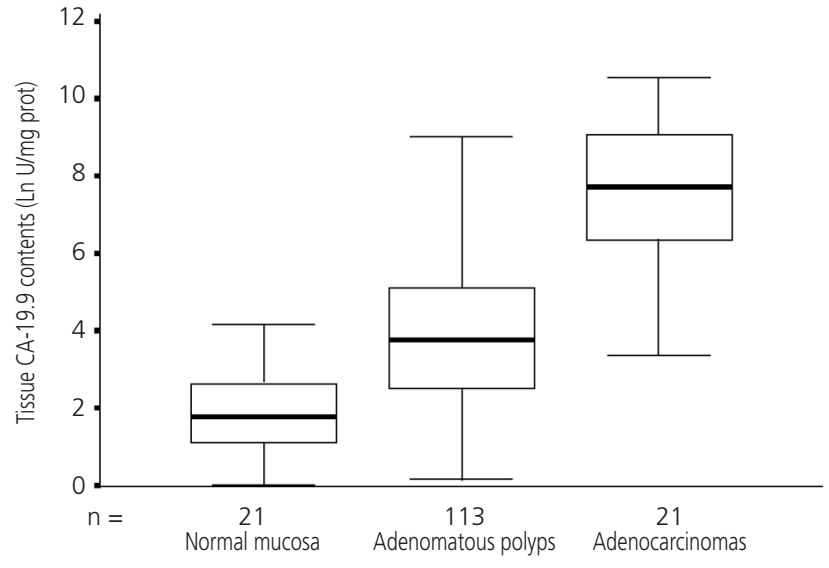

Fig.1. Box and whisker plots showing tissue CA-19.9 contents ( $L n$ U/mg protein) in normal colorectal mucosa, adenomatous polyp, and colorectal adenocarcinoma. Median concentration is denoted by the line inside the box, 25-75 percentiles as the box, and outliers as capped vertical bars. Tissue CA-19.9 levels in normal mucosa are lower than those found in adenomatous polyps and colorectal adenocarcinoma $(p<0.001$, ANOVA).

$(339 \pm 1073 \mathrm{U} / \mathrm{mg})$ or adenocarcinomas $(7,859 \pm 11,601$ $\mathrm{U} / \mathrm{mg}$ ) (Fig. 1). Only in one of the 50 normal mucosa samples (2\%) CA-19.9 levels were higher than $50 \mathrm{U} / \mathrm{mg}$, whereas $53.1 \%$ of the adenomatous polyps had tissue levels of this antigen below $50 \mathrm{U} / \mathrm{mg}$. This mainly occurred in polyps with mild dysplasia $(91.6 \%)$, without villous component $(93.3 \%)$ or of less than $1 \mathrm{~cm}$ in size $(53.3 \%)$. In these groups of polyps, CA19.9 levels ranged between 0.3 and $219 \mathrm{U} / \mathrm{mg}$. Only in one case of adenocarcinoma CA-19.9 concentration was lower than $50 \mathrm{U} / \mathrm{mg}$. The diagnostic performance parameters for the threshold value of $50 \mathrm{U} / \mathrm{mg}$ were assessed in the normal mucosa versus the adenomas. Results were: S: 44\%; SP: 95\%; PPV: 98\%; NPV: 24\%; EF: $45 \%$ and PLH (95\% confidence interval): $9.3(1.9-52.7)$.

\section{Tissue CA-19.9 levels in relation to polyp characteristics}

Size. Tissue CA-19.9 levels in polyps smaller than $1 \mathrm{~cm}$ in size were $54 \pm 77 \mathrm{U} / \mathrm{mg}$, while in those measuring between 1 and $2 \mathrm{~cm}$ these levels rose to $285 \pm 1145 \mathrm{U} / \mathrm{mg}$, and to $751 \pm 393 \mathrm{U} / \mathrm{mg}$ in polyps with diameters exceeding $2 \mathrm{~cm}$. These differences were statistically significant $(\mathrm{p}<0.001)$ (Table I).

Histologic type. In tubulovillous and villous polyps, CA-19.9 levels were significantly higher $(920 \pm 1669$ $\mathrm{U} / \mathrm{mg})(\mathrm{p}<0.001)$ than in tubular adenomas $(139 \pm 676$ $\mathrm{U} / \mathrm{mg}$ ) (Table I).

Grade of dysplasia. The content of CA-19.9 in polyps increased with the grade of dysplasia. In polyps with mild
Table I. Tissue CA-19.9 contents for adenomatous polyps (U/mg)

\begin{tabular}{lcc}
\hline Size $\left(^{*}\right)$ & No. polyps & CA-19.9 (U/mg) \\
\hline$<1 \mathrm{~cm}$ & 32 & $54 \pm 77$ \\
$1-2 \mathrm{~cm}$ & 52 & $285 \pm 1145$ \\
$>2 \mathrm{~cm}$ & 29 & $751 \pm 393$ \\
Histological type $\left(^{*}\right)$ & & \\
$\quad$ Without villous component & 84 & $139 \pm 676$ \\
With villous component & 29 & $920 \pm 1669$ \\
Grade of dysplasia (*) & & \\
Low & 91 & $195 \pm 871$ \\
Mild & 47 & $74 \pm 123 \square$ NS \\
Moderate & 44 & $325 \pm 1241 \square(* *)$ \\
High & 22 & $933 \pm 1561$ \\
$\quad$ Severe & 17 & $951 \pm 1731 \square(*)$ \\
Carcinoma in situ & 5 & $875 \pm 897 \square$ NS \\
\hline
\end{tabular}

U/mg: units per milligram of protein; NS: no significance; $\left({ }^{*}\right)$ : $p<0.001 ;(* *)$ : $\mathrm{p}<0.01$. All data are expressed as mean \pm standard deviation.

dysplasia, CA-19.9 levels were $74 \pm 123 \mathrm{U} / \mathrm{mg}$, whereas these levels increased to $325 \pm 1241 \mathrm{U} / \mathrm{mg}$ in polyps with moderate dysplasia and to $951 \pm 1731 \mathrm{U} / \mathrm{mg}$ in polyps with severe dysplasia. In polyps with CIS, the levels of this antigen were similar to those found in polyps with severe dysplasia $(875 \pm 897 \mathrm{U} / \mathrm{mg})$. Differences among these four groups of polyps were statistically significant $(\mathrm{p}<0.001)$. Nevertheless, no significant differences existed in the tissue levels of CA-19.9 between polyps with mild and moderate dysplasia or between adenomas with severe dysplasia and CIS. On the contrary, A-19.9 levels were significantly higher in polyps with severe dysplasia versus those with moderate dysplasia $(\mathrm{p}<0.01)$. The significance of the difference $(\mathrm{p}<0.001)$ persisted when polyps were gathered into two groups: one included polyps with mild or moderate dysplasia $(195 \pm 871 \mathrm{U} / \mathrm{mg})$; the other comprised polyps with severe dysplasia or CIS $(933 \pm 1561 \mathrm{U} / \mathrm{mg})$ (Table I). These groups were called "low-grade dysplasia" and "high-grade dysplasia", respectively.

\section{CA-19.9 diagnostic performance parameters to assess severe dysplasia}

To establish whether the measurement of CA-19.9 levels in polyps can recognize severe dysplasia or CIS, several cut-off levels were chosen. As table II shows, the cut-off value with the highest sensitivity and specificity was $214 \mathrm{U} / \mathrm{mg}$. The areas under the ROC curves for size, villous component and dysplasia grade were $0.66,0.84$ and 0.78 , respectively. For polyps with high risk (large size, villous component and severe dysplasia) and low risk of malignant transformation (small, tubular, mild or moderate grade dysplasia), these areas under the ROC curves were 0.84 and 0.81 , respectively (Fig. 2). 


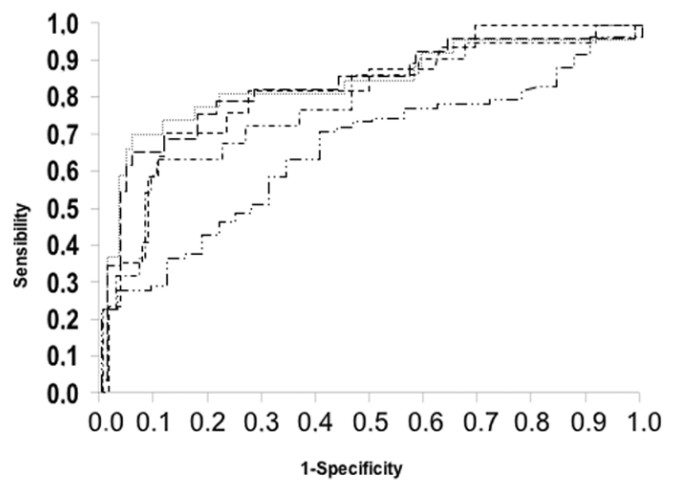

- - ROC curve for villous component. Area $=0.8387$. Standard Error $=0.0492$ - - . . ROC curve for high-grade dysplasia (severe dysplasia or cancer in situ). Area $=0.7827$. Standard Error $=0.0596$ - - - - ROC curve for polyps smaller than $1 \mathrm{~cm}$ in size, without villous component and low-grade dysplasia. Area $=0.8165$. Standard Error $=0.0593$ Ger with villous component and hig-grade dysplasia.

$-\cdots-R O C$ curve for polyp size (smaller than $1 \mathrm{~cm}$ in size). Area $=0.6649$. Standard Error $=0.0528$

Fig. 2. ROC curves for tissue CA-19.9 contents in adenomas and different variables and groups of risk for malignancy.

\section{DISCUSSION}

The present study shows that cytosol CA-19.9 levels are increased in adenomatous polyps and adenocarcinomas (Fig. 1). This finding concurs with those reported by Fischbach and Mössner (19), and Imamura et al. (21), who suggested that tissue antigen measurement might be useful to assess the grade of dysplasia in colorectal adenomas.

CA-19.9 levels were usually under $50 \mathrm{U} / \mathrm{mg}$ in the normal mucosa and in polyps with low risk of malignant transformation (small, without villous component, and low grade of dysplasia); therefore, this value allows to differentiate these types of mucosa from adenocarcinoma (PLH: 9.3, SP: 95\%, PPV: 98\%). However, our study also shows that cytosolic CA-19.9 levels vary widely both in polyps and adenocarcinomas. This finding has also been observed by other authors $(20,35)$. A loss of the capacity of tumor cells to synthesize or release this antigen may be an explanation for these variable levels of tissue CA19.9. Other possible explanations include the irregular distribution of lesions and the presence of wide necrotic areas within tumors (20).

Our study also shows that there are significant relationships between cytosolic CA-19.9 levels and the size, proportion of villous component and grade of dysplasia in adenomatous polyps. Thus, large polyps with severe dysplasia and more villous component had higher cytosolic CA-19.9 levels than small adenomas with low dysplasia and no villous component. Fischbach and Mössner (19), and Imamura et al. (21) also studied the relationship between tissue CA-19.9 contents and grade of dysplasia in colorectal adenomatous polyps. However, they could not demonstrate any significant relationship between them. The reason for the difference between the results obtained by these authors (21) is not clear, although the number of samples studied was relatively small and the methods used to measure tissue CA-19.9 concentrations were different.

When the CA-19.9 levels were compared in polyps with different grades of dysplasia, we found that there were no significant differences between polyps with mild and moderate dysplasia or polyps with severe dysplasia and CIS. However, differences were significant when CA-19.9 levels in polyps with mild or moderate dysplasia were compared to those in polyps with severe dysplasia or CIS. Thus, as tissue levels of CA-19.9 increase, so do the grade of dysplasia and risk of malignant transformation. It confirmed the usefulness of separating two groups of polyps, which are characterized by dysplasia (low and high grade) and therefore a low and high risk of malignant transformation, as reported by the US National Polyp Study (11).

ROC curves are useful tools to show the quality of information obtained by a specific test (31-34). When the ROC curve for high-grade dysplasia was performed and tissue CA-19.9 contents provided good discrimination (area $=0.78$ ), we found that $214 \mathrm{U} / \mathrm{mg}$ of CA-19.9 was the threshold value with the highest discrimination potential (S: 63\%; SP: 89\%; EF: 84\%). This value allows a classification of polyps with high-grade dysplasia (severe dysplasia or CIS), and to differentiate them from those with low-grade dysplasia (mild or moderate dysplasia).

We concluded that cytosolic CA-19.9 levels increase steadily from the normal colonic mucosa through colorectal adenoma to adenocarcinoma. The threshold value

Table II. Diagnostic performance parameters to assess severe dysplasia

\begin{tabular}{ccccccc}
\hline $\begin{array}{c}\text { CA-19.9 } \\
\text { (U/mg protein) }\end{array}$ & S (\%) & SP (\%) & PPV (\%) & NPV (\%) & EF (\%) & PLH (\%) \\
\hline 50 & 73 & 64 & 33 & 91 & 72 & 2.0 \\
100 & 68 & 73 & 38 & 90 & 91 & 84 \\
214 & 63 & 89 & 58 & 90 & 91 & 5.8 \\
250 & 59 & 90 & 57 & 84 & 88 & 10.3 \\
500 & 23 & 98 & 71 & & & \\
\hline
\end{tabular}

S. sensivity; SP: specificity; PPV: positive predictive value; NPV: negative preditive value; EF: efficiency; PLH: positive likelihood ratio 
$214 \mathrm{U} / \mathrm{mg}$ allows distinguishing polyps with low potential for malignant transformation from those with a higher risk of malignant transformation. Therefore, the measurement of CA-19.9 content in polyps may be a useful parameter for their classification when histology is conflicting. These results could also be useful in the clinical setting, although endoscopic surveillance may be more frequent for this type of polyps or the consideration of additional therapy.

\section{REFERENCES}

1. Winawer SJ. Natural history of colorectal cancer. Am J Med 1999; 106:3S-6S; discussion 50S-51S

2. Winawer $\mathrm{S}$, Zauber $\mathrm{A}$. The advanced adenoma as the primary target of screening. Gastrointest Endosc Clin N Am 2002; 12: 1-9,v.

3. Winawer S, Fletcher R, Douglas R, Bond J, Burt R, Ferrucci J, et al. Colorectal cancer screening and surveillance: clinical guidelines and rationale-update based on new evidence. Gastroenterology 2003; 124: $544-60$.

4. Itzkowitz SH, Kim YS. Colonic polyps and polyposis syndromes. En: Feldman M, Scharschmidt BF, Sleisenger MH, eds. Sleisenger and Fordtran's Gastrointestinal and Liver disease. Pathophisiology, Diagnosis, Management. 6th Ed; Vol. II. Philadelphia: WB. Saunders. 1998. p. 1865-905.

5. Itzkowitz SH. Gastrointestinal adenomatous polyps. Semin Gastrointest Dis 1996; 7: 105-16.

6. Winawer SJ. Appropriate intervals for surveillance. Gastrointest Endosc 1999; 49: S63-66.

7. Brown LJ, Smeeton NC, Dixon MF. Assessment of dysplasia in colorectal adenomas: an observer variation and morphometric study. J Clin Pathol 1985; 38: 174-9.

8. Dixon MF, Brown LJ, Gilmour HM, Price AB, Smeeton NC, Talbot IC, et al. Observer variation in assessment of dysplasia in ulcerative colitis. Histopathology 1988; 13: 385-97.

9. Jensen P, Krogsgaard M, Christiansen J, Braendstrup O, Johansen A, Olsen J. Observer variability in the assessment of type and dysplasia of colorectal adenomas, analyzed using kappa statistics. Dis Colon Rectum 1995; 38: 195-8.

10. Rex D, Alikhan M, Cummings O, Ulbright TM. Accuracy of pathologic interpretation of colorectal polyps by general pathologists in community practice. Gastrointest Endosc 1999; 50: 468-74.

11. Bond JH. Follow-up after polypectomy: Consensus? Eur J Cancer 1995; 31A: 1141-4.

12. Koprowski H, Steplewski Z, Mitchell K, Herlyn M, Herlyn D, Fuhrer P. Colorectal carcinoma antigens detected by hybridoma antibodies. Somatic Cell Genet 1979; 5: 957-71.

13. Koprowski H, Herlyn M, Steplewski Z, Sears HF. Specific antigen in serum of patients with colon carcinoma. Science 1981; 212: 53-5.

14. Magnani JL, Brockhaus M, Smith DF, Ginsburg V, Blaszczyk Mitchell $\mathrm{KF}$, et al. A monosialoganglioside is a monoclonal antibody-defined antigen of colon carcinoma. Science 1981; 212: 55-6.

15. Koprowski H, Brockhaus M, Blaszczyk M, Magnani J, Steplewski Z, Ginsburg V. Lewis Blood-type may affect the incidence of gastrointestinal cancer. Lancet 1982; 1: 1332-3.

16. Magnani JL, Nilsson B, Brockhaus M, Zopf D, Steplewski Z,
Koprowski H, et al. A monoclonal antibody-defined antigen associated with gastrointestinal cancer is a ganglioside containing sialylated lacto-N-fucopentaose II. J Biol Chem 1982; 257 : 14365-9.

17. Lindholm L, Holmgren J, Svennerholm L, Fredman P, Nilsson O, Persson B, et al. Monoclonal antibodies against gastrointestinal tumour-associated antigens isolated as monosialogangliosides. Int Arch Allergy Appl Immunol 1983; 71: 178-81.

18. Fukuta S, Magnani JL, Gaur PK, Ginsburg V. Monoclonal antibody CC3C195, which detects cancer-associated antigens in serum, binds to the human Lea blood group antigen and to its sialylated derivative. Arch Biochem Biophys 1987; 255: 214-6.

19. Filella X, Molina R, Grau JJ, Piqué JM, García-Valdecasas JC, Astudillo E, et al. Prognostic value of CA 19.9 levels in colorectal cancer. Ann Surg 1992; 216: 55-9.

20. Fischbach W, Mössner J. Tissue concentrations of CEA and CA 19.9 in the carcinogenesis of colorectal carcinoma exemplified by the adenoma-carcinoma sequence. Res Exp Med 1988; 188: 101-14.

21. Imamura Y, Yasutake K, Yoshimura Y, et al. Contents of tissue CEA and CA 19.9 in colonic polyp and colorectal cancer, and their clinical significance. Gastroenterol Jpn 1990; 25: 186-92.

22. Konishi F, Morson BC. Pathology of colorectal adenomas: a colonoscopic survey. J Clin Pathol 1982; 35: 830-41.

23. Maratka Z. Terminology, definitions and diagnostic criteria in digestive endoscopy. With the collaboration of the members of the Terminology Committee of the World Society of Digestive Endoscopy/OMED. Scand J Gastroenterol 1984; 103 (Supl.): 1-74.

24. Blackstone MO. Colonic polyps. En: Endoscopic interpretation. Normal and pathologic appearances of the gastrointestinal tract. New York: Raven Press, 1984: 429-49.

25. Lowry OH, Rosebrough NJ, Farr AL. Protein measurement with the Folin-phenol reagent. J Biol Chem 1951; 193: 265-75.

26. O'Brien MJ, Winner SJ, Zauber AG, Gottlieb LS, Sternberg SS, Diaz B, et al. The National Polyp Study. Patient and polyp characteristics associated with high-grade dysplasia in colorectal adenomas. Gastroenterology 1990; 98: 371-9.

27. Linares-Santiago E, Gómez-Parra M, Pellicer-Bautista F, RomeroCastro R, Caunedo-Álvarez A, Mendoza-Olivares FJ, et al. The assessment of colonic polyps found via colonoscopy. Gastroenterol Hepatol 1999; 22: 273-8.

28. Compton C, Henson D, Hutter R, Sobin LH, Bowman HE. Updated protocol for the examination of specimens removed from patients with colorectal carcinoma. A basis for checklists. Arch Pathol Lab Med 1997; 12: 1247-54.

29. Altman DG, Bland JM. Diagnostic tests 1: sensitivity and specificity. BMJ 1994; 308: 1552.

30. Altman DG, Bland JM. Diagnostic tests 2: predictive values. BMJ 1994; 309: 102

31. Altman DG, Bland JM. Diagnostic tests 3: receiver operating characteristic plots. BMJ 1994; 309: 188.

32. Zweig MH, Campbell G. Receiver operating characteristic (ROC) plots: a fundamental evaluation tool in clinical medicine. Clin Chem 1993; 39: 561-77.

33. Altman DG. ROC curves and confidence intervals: getting them right Heart 2000; 83: 236.

34. Hanley JA, McNeil BJ. The meaning and use of the area under a receiver operating characteristic (ROC) curve. Radiology 1982; 143: 29-36.

35. Wagener Ch, Müller-Wallraf R, Nisson S, Groner J, Breuer H. Localization and concentration of carcinoembryonic antigen (CEA) in gastrointestinal tumors: correlation with CEA levels in plasma. J Natl Cancer Inst 1981; 67: 539-47. 


\title{
Detección de CA-19.9 citosólico en adenomas colorrectales. Utilidad en el diagnóstico de la displasia
}

\author{
I. Salces, I. Vegh², S. Rodríguez-Muñoz, F. Colina ${ }^{1}$, A. Pérez ${ }^{1}$, S. Soto, F. Sánchez, J. de la Cruz \\ y J. A. Solís-Herruzo \\ Servicios de Medicina de Aparato Digestivo, ${ }^{1}$ Anatomía Patológica, ${ }^{2}$ Unidad de Investigación del Centro de \\ Investigación y ${ }^{3}$ Unidad de Epidemiología Clínica. Hospital Universitario 12 de Octubre. Madrid
}

\section{RESUMEN}

Introducción: en ocasiones, el riesgo de transformación maligna de los pólipos adenomatosos es difícil de identificar por existir zonas con distintos grados de displasia simultáneamente. La determinación tisular de los marcadores tumorales puede ser útil para clasificar estos adenomas.

Objetivos: conocer la relación existente entre las tasas de antígeno carbohidratado 19.9 citosólico (CA-19.9) del tejido colónico y las características morfológicas de los pólipos, para posteriormente valorar la utilidad diagnóstica de esta medición.

Pacientes y métodos: se estudiaron histológicamente 155 muestras de colon (21 muestras de mucosa normal, 113 pólipos adenomatosos y 21 adenocarcinomas) en las que además se determinó la concentración tisular de CA-19.9 mediante enzimoinmunoanálisis.

Resultados: los niveles de CA-19.9 citosólico en los pólipos adenomatosos y los adenocarcinomas fueron significativamente más altos que los encontrados en la mucosa normal. En los adenomas, estos niveles variaban significativamente con el tamaño, el tipo histológico y el grado de displasia. El contenido de CA-19.9 tisular en los pólipos con alto grado de displasia fue mayor que en los de bajo riesgo de displasia. La tasa de $214 \mathrm{U} / \mathrm{mg}$ de proteína diferenció adecuadamente ambos tipos de pólipos. Al estimar las áreas bajo las curvas de eficacia diagnóstica se demostró que los niveles citosólicos de CA-19.9 permiten clasificar los pólipos adenomatosos de acuerdo con sus características histológicas.

Conclusiones: la determinación tisular de CA-19.9 puede ser útil en la evaluación de los pólipos adenomatosos y confirma la posibilidad de clasificar los adenomas en dos grupos: bajo y alto grado de transformación maligna.

Palabras clave: Adenoma colorrectal. Pólipos colónicos. Marcadores tumorales tisulares. CA-19.9. Grado de displasia.

\section{INTRODUCCIÓN}

Es bien sabido que los adenomas de colon son neoplasias con potencial maligno que se desarrollan en aproximadamente 10 a 20 años y que el riesgo de malignización está relacionado con su tamaño, la existencia o no de componente velloso y grado de atipia celular (1-6). En ocasiones, es difícil clasificar histológicamente el tipo de pólipo, ya que el grado de displasia varía de unas zonas a otras (7-10). La posibilidad de clasificar los adenomas en grupos según el riesgo de malignización puede ser impor- tante para determinar qué pólipos deben extirparse preferentemente, si la vigilancia endoscópica debe ser más exhaustiva o si hay que asociar algún otro tratamiento coadyuvante $(2,3,11)$.

El antígeno carbohidratado 19.9 (CA-19.9) es una proteína relacionada con el antígeno sialilado Lewis, que se expresa en la membrana celular y el citosol de la mucosa normal y los adenocarcinomas colorrectales humanos (12-18). La concentración sérica de CA-19.9 se utiliza como marcador tumoral, en especial en el cáncer de páncreas y colon. Diversos estudios han demostrado que es de utilidad en el diagnóstico de estas enfermedades, la eficacia del tratamiento quirúrgico y en la detección de las recidivas tumorales (19-21). Sin embargo, este marcador tumoral a veces no se detecta en la sangre de los pacientes con lesiones preneoplásicas, cáncer temprano o, incluso tumores avanzados. Esta baja sensibilidad se debe a que las células tumorales llegan a ser tan anormales que pierden su capacidad para sintetizar o segregar la proteína tumoral $(20,21)$. Su especificidad en sangre también es baja ya que puede estar elevado en otros tumores como los de vesícula biliar, hígado, estómago y mama, o en enfermedades no neoplásicas como pancreatitis, hepatopatías y enfermedades autoinmunes. La determinación de este antígeno en el tejido colónico pudiera ser más sensible y específica para reconocer un mayor riesgo de malignización de los pólipos adenomatosos. En el presente estudio analizamos las tasas de CA-19.9 en tejido colónico, su relación con las características histológicas de los pólipos (componente velloso, grado de displasia, tamaño) y la utilidad diagnóstica de su determinación.

\section{MATERIAL Y MÉTODOS}

\section{Pacientes}

Se incluyeron en el estudio 145 pacientes (48 mujeres y 97 hombres) a los que se realizó una colonoscopia hasta ciego. En todos los casos se solicitó el consentimiento 
informado de los pacientes antes de ser incluidos en el estudio. Se obtuvieron endoscópicamente 155 muestras colorrectales, de las que 21 procedían de mucosas normales y otras 21 de adenocarcinomas. Las otras 113 muestras fueron pólipos adenomatosos. Todas las muestras se dividieron en dos partes; una parte se fijó en formol al 10\% para su estudio histológico y la otra parte se almacenó a $-80{ }^{\circ} \mathrm{C}$ hasta la determinación del CA-19.9 citosólico (4, 22-24).

\section{Determinación tisular del antígeno CA-19.9}

La determinación tisular de CA-19.9 en la mucosa colónica se realizó mediante un enzimoinmunoanálisis de micropartículas (MEIA). Los resultados obtenidos con esta técnica están estrechamente correlacionados con los que se logran cuando se emplea el radioinmunoanálisis (RIA) (CA-19.9 RIA-gnost. CIS Diagnostic. Madrid). El tejido fue descongelado y homogeneizado a $4{ }^{\circ} \mathrm{C}$ en una solución tampón. La suspensión se sometió a ultracentrifugación a $106.000 \mathrm{~g}$ durante 30 minutos para posteriormente recoger el sobrenadante en el que se midió el CA19.9 y la concentración total de proteínas. El antígeno se determinó mediante un análisis comercial (Abbott Científica, Madrid. Spain) que utiliza el anticuerpo monoclonal 1116-NS-19.9 (12) frente al determinante antigénico carbohidratado expresado en la superficie celular. Los valores del antígeno CA-19.9 tisular se expresaron en unidades por miligramo de proteína (U/mg prot). Las concentraciones de proteínas en las muestras de tejido fueron determinadas siguiendo el método de Lowry y cols. (25) (Bio-Rad Laboratories, Madrid, Spain).

\section{Análisis histológico}

El tejido fijado en formol fue procesado de forma habitual para estudio histológico y fue analizado por dos patólogos independientes, careciendo de cualquier información sobre las tasas de CA-19.9 tisular. Se valoró el tipo histológico de los adenomas (tubular, velloso o túbulo-velloso) y el grado de displasia (leve, moderada, intensa o con carcinoma in situ).

Los criterios empleados para diagnosticar la displasia leve fueron la presencia de criptas elongadas o ramificadas con células epiteliales de núcleos ovales, alargados, basales y con superposición regular, de cromatina fina y nucleólos poco patentes.

El diagnóstico de displasia moderada se estableció cuando las células epiteliales presentaban núcleos que habían perdido su polaridad basal, las membranas nucleares eran irregulares, la cromatina presentaba un patrón más denso y los nucleólos eran más prominentes.

Se consideró que existía displasia severa cuando la lámina propia estaba muy reducida, las glándulas presentaban irregularidades complejas, ocasionalmente formando papilas, sus núcleos eran grandes e irregulares al igual que sus membranas y la cromatina estaba alterada (vesicular, hipercromática o granular).

El carcinoma intramucoso o in situ (CIS) fue definido como una alteración arquitectural glandular intensa de patrón cribiforme y formación de imágenes glandulares de "espalda contra espalda", formación de nidos sólidos y rasgos citológicos propios de la displasia intensa (26-28).

\section{Análisis estadístico}

Todos los datos se expresaron como media \pm desviación estándar. Realizamos una transformación logarítmica para comparar las concentraciones tisulares de CA19.9 debido a la asimetría y dispersión de los valores. El comportamiento estadístico de los valores absolutos del antígeno así como el de sus logaritmos fue similar en todos los casos. Las comparaciones entre todos los grupos se efectuaron mediante un análisis de varianza (ANOVA). Consideramos significativos los resultados cuando el valor de $p$ era inferior a 0,05 . Asimismo, se calcularon los índices de sensibilidad (S), especificidad (SP), valor predictivo positivo (VPP), valor predictivo negativo (VPN), eficacia diagnóstica (EF) y cociente de probabilidad positivo (LHP) para distintos valores de CA-19.9 tisular $(29,30)$. Se representó la curva de eficacia diagnóstica o curva ROC (receiver operating characteristic) para los distintos marcadores morfológicos y grupos de riesgo de evolución a carcinoma colorrectal y se estimaron y compararon sus áreas (31-34). Para todo ello se utilizó el programa estadístico SAS (SAS Institute Inc., Cary NC 27513).

\section{RESULTADOS}

\section{Tasas de antígeno CA-19.9 en tejido e índices de utilidad diagnóstica}

La tasa de CA-19.9 en la mucosa normal fue de $12,3 \pm 17,3 \mathrm{U} / \mathrm{mg}$ prot, que fue significativamente inferior $(p<0,001)$ a la hallada en los pólipos adenomatosos $(339 \pm 1.073 \mathrm{U} / \mathrm{mg}$ prot.) y en los adenocarcinomas $(7.859 \pm 11.601 \mathrm{U} / \mathrm{mg}$ prot.) (Fig. 1). Tan sólo en una biopsia de mucosa normal (2\%) hallamos tasas de CA19.9 superiores a $50 \mathrm{U} / \mathrm{mg}$ prot. El 53,1\% de los pólipos adenomatosos tuvieron tasas tisulares de CA-19.9 inferiores a $50 \mathrm{U} / \mathrm{mg}$ prot. Esto ocurrió preferentemente en pólipos con displasia leve o moderada $(91,6 \%)$, sin componente velloso $(93,3 \%)$ o de menos de $1 \mathrm{~cm}$ de diámetro $(53,3 \%)$. En estos, las tasas de CA-19.9 en tejido polipoideo oscilaron entre 0,3 y $219 \mathrm{U} / \mathrm{mg}$ prot. De los adenocarcinomas estudiados sólo uno tenía tasas de CA-19.9 menor de $50 \mathrm{U} / \mathrm{mg}$ prot. Calculamos los índices de utilidad diagnóstica entre la mucosa normal y la adenomatosa para el valor de corte $50 \mathrm{U} / \mathrm{mg}$ prot. Estos 
índices fueron S: 44\%; SP: 95\%; VPP: 98\%; VPN: 24\%; EF: $45 \%$ y LHP para IC 95\%: 9,3 $(1,9-52,7)$.

\section{Tasas de CA-19.9 en tejido colónico en relación con las características de los pólipos}

Tamaño. En los pólipos de menos de $1 \mathrm{~cm}$, las tasas de CA-19.9 fueron de $54 \pm 77 \mathrm{U} / \mathrm{mg}$ prot., mientras que en los que medían entre 1 y $2 \mathrm{~cm}$, esas tasas ascendieron a $285 \pm 1145 \mathrm{U} / \mathrm{mg}$ prot. y en los que su diámetro superaba los $2 \mathrm{~cm}$, a $751 \pm 1.393 \mathrm{U} / \mathrm{mg}$ prot. Las diferencias entre ellos alcanzaron significación estadística $(\mathrm{p}<0,001)$ (Tabla I).

Tipo histológico. Las tasas de CA-19.9 en los pólipos túbulo-vellosos y vellosos (920 $\pm 1.669 \mathrm{U} / \mathrm{mg}$ prot.) fueron significativamente más altas $(\mathrm{p}<0,001)$ que en los tubulares (139 $\pm 676 \mathrm{U} / \mathrm{mg}$ prot) (Tabla I).

Tabla I. Tasas tisulares de CA-19.9 en los pólipos adenomatosis

\begin{tabular}{lcc}
\hline Tamaño $\left(^{*}\right)$ & $N^{0}$ pólipos & CA-19.9 (U/mg) \\
\hline$<1 \mathrm{~cm}$ & 32 & $54 \pm 77$ \\
$1-2 \mathrm{~cm}$ & 52 & $285 \pm 1145$ \\
$>2 \mathrm{~cm}$ & 29 & $751 \pm 393$ \\
Tipo histológico $\left(^{*}\right)$ & & \\
$\quad$ in componente velloso & 84 & $139 \pm 676$ \\
Con componente velloso & 29 & $920 \pm 1669$ \\
Grado de displasia $\left(^{*}\right)$ & & \\
$\quad$ Bajo & 91 & $195 \pm 871$ \\
Leve & 47 & $74 \pm 123 \square$ NS \\
Moderado & 44 & $325 \pm 1241 \square(* *)$ \\
Alto & 22 & $933 \pm 1561$ \\
$\quad$ Severo & 17 & $951 \pm 1731 \square$ (*) \\
Carcinoma in situ & 5 & $875 \pm 897 \square$ NS \\
\hline
\end{tabular}

U/mg: unidades por milígramo de proteína; NS: no significativo; $\left(^{*}\right)$ : $p<0,001$; $(* *): p<0,01$. Todos los datos se expresan como media \pm desviación estándar.

Grado de displasia. Las tasas de CA-19.9 aumentaron a medida que lo hacía el grado de displasia. Mientras que en los pólipos con displasia leve la tasa de este antígeno era de $74 \pm 123 \mathrm{U} / \mathrm{mg}$ prot., en los que tenían displasia moderada ascendió a $325 \pm 1241 \mathrm{U} / \mathrm{mg}$ prot. y a $951 \pm$ $1.731 \mathrm{U} / \mathrm{mg}$ prot. en los que tenían displasia severa. Las tasas de CA-19.9 en el grupo de pólipos con CIS, fue similar al grupo anterior $(875 \pm 897 \mathrm{U} / \mathrm{mg}$ prot.). Las diferencias entre los pólipos con displasia leve y moderada y entre los que tenían displasia intensa y CIS no fueron significativas, en cambio sí lo fueron $(\mathrm{p}<0,01)$ entre los pólipos con displasia moderada e intensa. La significación estadística $(\mathrm{p}<0,001)$ persistía cuando los pólipos se distribuían en dos grupos: un grupo formado por los pólipos con displasia leve o moderada ( $195 \pm 871 \mathrm{U} / \mathrm{mg}$ prot.) y otro grupo el comprendido por los pólipos con displasia severa y CIS $(933 \pm 1.561 \mathrm{U} / \mathrm{mg}$ prot.) (Tabla I). Estos grupos se denominaron displasia de bajo grado y displasia de alto grado respectivamente.

\section{Índices de rendimiento diagnóstico del CA-19.9 para el reconocimiento de la displasia severa}

Se eligieron algunos valores de corte al azar de CA19.9 tisular para establecer si su determinación en los pólipos adenomatosos reconocía la displasia severa o el CIS. En la tabla II se muestra que el punto de corte que proporcionó índices de sensibilidad y de especificidad más altos fue el de $214 \mathrm{U} / \mathrm{mg}$ prot.

El cálculo del área bajo la curva ROC para el tamaño, componente velloso y grado de displasia de los pólipos fue de $0,66,0,84$ y 0,78 , respectivamente. Las áreas bajo la curva ROC para los pólipos de alto riesgo de malignización (gran tamaño, componente velloso y displasia severa) y de bajo riesgo (pequeños, tubulares, displasia leve o moderada) fueron de 0,84 y 0,81 , respectivamente (Fig. 2).

\section{DISCUSIÓN}

Nuestro estudio muestra que la tasa de antígeno CA19.9 en el tejido colónico está significativamente aumentada en los pólipos adenomatosos y en los adenocarcinomas (Fig. 1). Hallazgos similares fueron descritos por Fischbach y Mössner (19) e Imamura y cols. (21) que llegaron a sugerir que la determinación de CA-19.9 y antígeno carcinoembrionario podría ser de utilidad diagnóstica para precisar el grado de displasia en los adenomas colorrectales.

Tabla II. Índices de rendimiento diagnóstico para el reconocimiento de la displasia severa

\begin{tabular}{ccccccc}
\hline $\begin{array}{c}\text { CA-19.9 } \\
\text { (U/mg prtotein) }\end{array}$ & S (\%) & SP (\%) & PPV (\%) & NPV (\%) & EF (\%) & PLH (\%) \\
\hline 50 & 73 & 64 & 33 & 91 & 72 & 2,0 \\
100 & 68 & 73 & 38 & 90 & 78 & 2,5 \\
214 & 63 & 89 & 58 & 91 & 84 & 5,8 \\
250 & 59 & 90 & 57 & 90 & 91 & 5,4 \\
500 & 23 & 98 & 71 & 84 & 88 & 10,3 \\
\hline
\end{tabular}

S. sensibilidad; SP: especificidad; PPV: valor predictivo positivo; NPV: valor predictivo negativo; EF: eficacia diagnóstica; PLH: consciente de probabilidad positivo. 


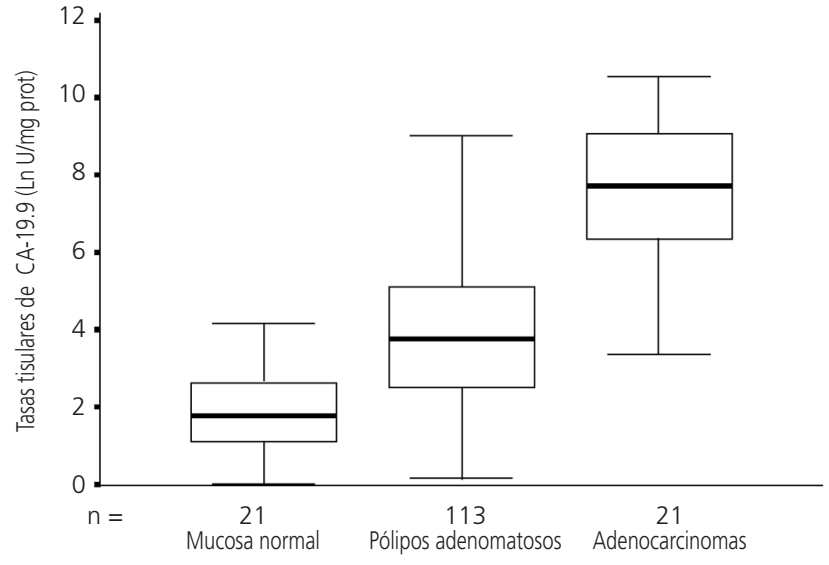

Fig. 1. Diagrama de cajas de los valores tisulares de CA-19.9 (Ln U/mg de proteína) obtenidos en mucosa normal, pólipos adenomatosos y adenocarcinomas colorrectales. Los límites superior e inferior de las cajas representan los percentiles 25-75 y la línea gruesa de la caja corresponde a la concentración media del marcador tumoral. Los niveles citosólicos de CA-19.9 en la mucosa normal fueron significativamente menores $(p<0,001)$ que los hallados en los pólipos adenomatosos y los adenocarcinomas.

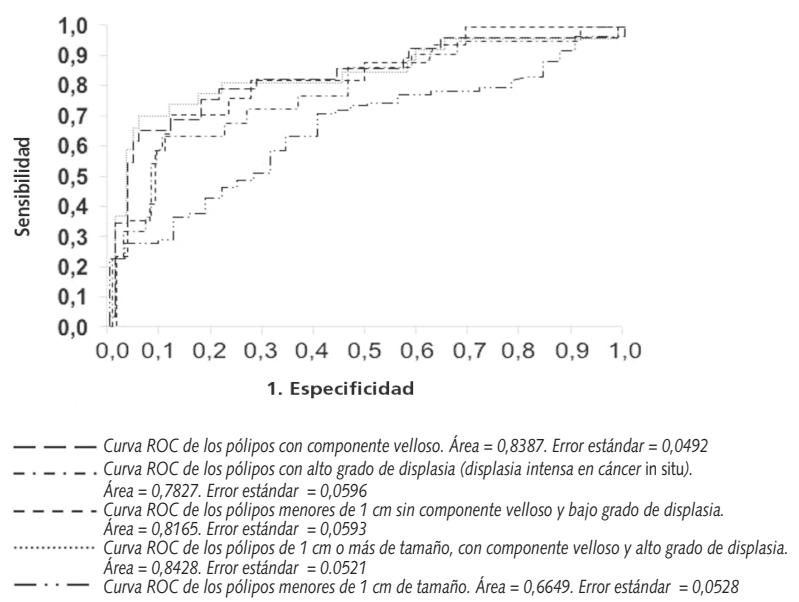

Fig. 2. Curvas ROC de los niveles de CA-19.9 tisulares para los distintos marcadores morfológicos y grupos de riesgo de malignización.

En la mucosa normal y en los pólipos con escaso riesgo de malignización (pequeños, tubulares y con displasia leve o moderada), la tasa de CA-19.9 tisular se suele situar por debajo de las $50 \mathrm{U} / \mathrm{mg}$ proteínas. Esta tasa de CA-19.9 clasifica de forma adecuada la mucosa normal y adenomatosa, y las diferencia del adenocarcinoma (LHP: 9.3; SP: 95\%; VPP: 98\%). Sin embargo, en nuestro estudio también se obtuvieron tasas de CA19.9 muy variables en adenomas con alto riesgo de malignización y en adenocarcinomas, lo cual ha sido des- crito también por otros autores $(20,35)$. La pérdida de la capacidad de las células tumorales para sintetizar o metabolizar la proteína, la distribución heterogénea de las lesiones dentro del mismo tumor así como la presencia de zonas necrosadas pueden explicar estas variaciones $(20,35)$.

El presente estudio muestra también que las tasas de CA-19.9 en los pólipos colónicos aumentan de forma significativa a medida que lo hace su tamaño, el grado de displasia o si se encuentran presentes estructuras vellosas. Por ello, los pólipos con displasia severa, componente velloso y de mayor tamaño tenían tasas de CA-19.9 más altas que cuando la displasia era leve, no había componente velloso o eran de pequeño tamaño. Fischbach y Mössner (19) e Imamura y cols. (21) compararon también los niveles de CA-19.9 tisulares con el grado de displasia, sin embargo, no encontraron significación estadística entre ellos. La causa de esta diferencia con nuestros resultados no está clara aunque el número de casos de esos estudios fue más reducido y la metodología empleada para la determinación del CA-19.9 fue diferente.

Al comparar las tasas de CA-19.9 en los pólipos clasificados según el grado de displasia, hallamos que existían diferencias estadísticamente significativas sólo entre los grupos con displasia moderada y severa, pero no entre los grupos de pólipos con displasia leve y moderada ni entre los pólipos con displasia severa y CIS. Es decir, las tasas de CA-19.9 tisular aumentan a la vez que lo hace el grado de displasia y el riesgo de malignización. Esto confirmaba la utilidad de diferenciar dos grupos de pólipos según el grado de displasia (bajo y alto grado) y por tanto de bajo y alto riesgo de malignización, como postulan otros autores $(2,3,11)$.

El análisis de la curva ROC expresa la calidad de la información obtenida con la prueba diagnóstica empleada (31-34). En nuestro estudio, el CA-19.9 tisular proporciona una buena discriminación de pólipos con alto grado de displasia y el valor de CA-19.9 con mayor eficiencia diagnóstica es el de $214 \mathrm{U} / \mathrm{mg}$ proteínas (S: 63\%; SP: 89\%; EF: 84\%). Esta tasa nos permite clasificar los pólipos con alto grado de displasia (displasia intensa o CIS) y diferenciarlos de aquellos con bajo grado de displasia (leve o moderada).

Concluimos, que existe un aumento progresivo de las tasas de CA-19.9 en la mucosa colónica normal, adenomatosa y adenocarcinoma. La tasa de CA-19.9 de 214 U/mg proteína permite diferenciar los pólipos con alto grado de displasia de los que tienen un riesgo bajo de transformación maligna. Es más, la determinación de CA-19.9 tisular en los pólipos de colon puede ser un parámetro útil cuando la evaluación histológica es difícil de clasificar. Estos resultados pueden ser de utilidad en la práctica clínica para vigilar endoscópicamente con más frecuencia este tipo de pólipos o considerar algún otro tratamiento adyuvante. 